\title{
Computation of Modal Properties of Two Types of Freight Wagon Bogie Frames Using the Finite Element Method
}

Ján Dižo, Jozef Harušinec, Miroslav Blatnický

Faculty of Mechanical Engineering, University of Žilina. Univerzitná 8215/1, 01025 Žilina. Slovak Republic. E-mail: jan.dizo@fstroj.uniza.sk, jozef.harusinec@fstroj.uniza.sk, miroslav.blatnicky@fstroj.uniza.sk

The aim of this article is to calculate and compare the modal properties of the frame of the standard and modified freight wagon bogie design. Analysed frames represent the main support parts of the bogie, which are most often used in the Central Europe region. Determination of the modal properties belongs to the fundamental but very important step in the engineering design. In our case, modal analyses of bogie frames structures were carried out using the Finite Element Method. In order to perform numerical calculations based on FEM approach, Ansys package was used. Modal analyses of individual parts as well as substructures of rail vehicles is an inseparable part of the rail vehicles design process. In this article theoretical and practical consequences of obtained results from the modal analysis, i.e. eigenmodes and eigenfrequences of the analysed part of the bogie on its dynamic properties are presented.

Keywords: Freight wagon bogie, Finite element method, Modal analysis, Modified design

\section{Introduction}

Modal analysis is a relatively young field of dynamics and in industry started to be used in the 80 's of the last century. Late inclusion into practice is associated with the development of software and hardware for finite element method. Modal analysis can be applied in theory, such as computational method or at practical level, such as real experimental measurements of mechanical structures. The modal parameters obtained from experimental analysis in engineering practice are often compared with the modal parameters obtained from computational methods $[4,10]$. The resulting modal parameters of modal analysis include eigenfrequencies, eigenmodes and modal damping of an analysed structure [19]. The great advantage of the mentioned is that the entire development process of rail vehicles is so accelerated and therefore leads to a reduction of overall costs. Simulations and subsequent optimisation of a rail vehicles structure is performed before production of a rail vehicle itself. This leads to minimising the number of unsatisfactory results conducted on a rail vehicle. This may, in such a stage of development lead to delays and increased costs. Computational models of rail vehicles and their components are more or less simplified compared with the actual ones. This simplification is seen when comparing the results from real experiments [24, 27].

\section{Application of modal analysis}

Methods of the modal analysis can solve many technical problems encountered in the design, manufacture and operation of mechanical systems or parts. Therea are also used in analyses of adverse events of mechanical systems, such as excessive noise, deformation, vibration, damage and so on.

Ride properties are significantly affected by the dynamic behaviour of a rail vehicles mechanical system [5, $11,12,25,29]$. We can theoretically predict the movement of the wheelset on a track by means of the wheelset and track geometric characteristics analysis $[15,16,20]$.
Geometric characteristics define the rail/wheel profiles contact couple geometrical relationship [21]. The shape of the contact couple crucial influences the size of the contact patch and contact stress between wheel and rail value $[6,18]$. This creates the loading and excitation forces acting inside vehicle and track systems. The analysis of the mechanical system dynamics may be analysed using various methods. Reasons for using various methods are:

- Comparison of data obtained from experimental measurement on a prototype with corresponding data obtained from the finite element method. Optimisation of an analytical model, which will be used for further calculations and simulations. This optimised model is free of errors, which were caused by the poor application of boundary conditions [17, 30, 29];

- With the resulting eigenfrequencies unsafe operating conditions can be determined, which are not allowed. If the eigenfrequencies and frequency of excitation are equal, the resonance occurs. This reduces operating life, increase noise and could damage the construction $[13,14]$;

- With the resulting mode shapes of vibrations we can determine the areas of maximum errors. Subsequently, it is possible to perform design modifications (geometry, additional elements, changing material characteristics, etc.), which eliminate dangerous vibration $[22,23]$;

- The resulting modal parameters are used for faults diagnostic and operation areas $[34,35]$.

\section{Application of modal analysis}

The modal analysis is the most common type of the 
dynamic calculation. It determines eigenmodes, eigenfrequencies and modal damping of rail vehicle mechanical systems and these parameters provide us with basic information on the dynamic behaviour of mechanical systems $[1,7]$.

At present, the modal analysis of mechanical systems is performed in computer programs that most often operate on the principle of the finite element method. The most commonly used programs are Ansys, Adina, Marc, Comsol, etc.

Using the modal analysis by the FEM requires to perform these steps [29, 31]:

- Create geometry of an analysed structure;

- Define material properties (density materials, Poisson's ratio, Young's modulus of elasticity of material);

- Define the boundary conditions for the creation of a computational model;

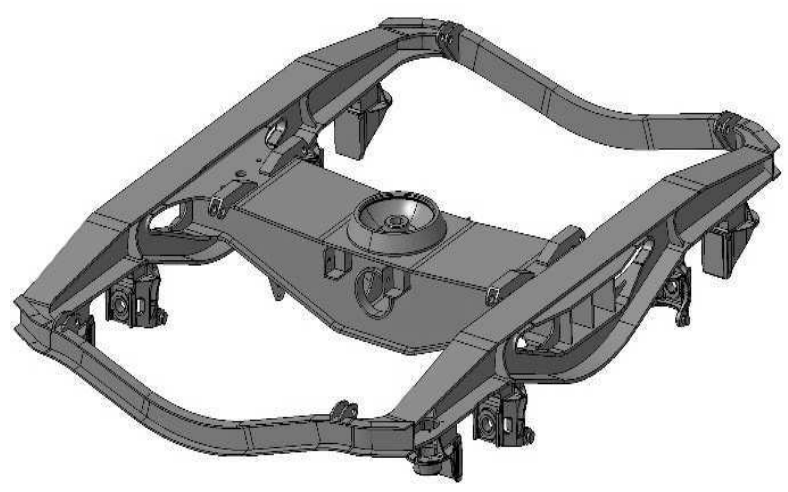

- Create a mesh of FEM, which consists of a suitably chosen element and its final size (smaller mesh, longer calculation);

- Set the solver which contains a suitable computational algorithm. Select the frequency range and number of wanted modes of vibrations in mechanical construction;

- Export modal parameters of the analysed construction.

\section{Analysed freight wagon bogie frames}

Analysed frames are the main construction and support part of the both original and modified Y25 bogie. The modified bogie is based on the original Y25 bogie, but the principal difference between them is that buffer beams are no longer part of the modified one. Figure 1 shows the design comparison of the original and modified freight wagon bogie frame created in Catia software.

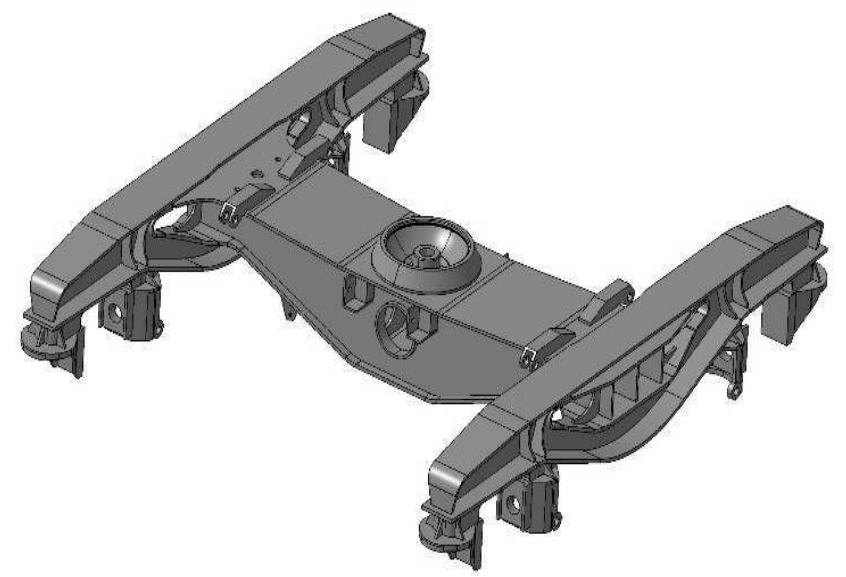

Fig. 1 Three-dimensional model of the original (left) and modified (right) freight wagon bogie frame

Generally, the Y25 bogie is equipped with a single suspension with duplex coil spring with linked characteristic curve a wheel guiding device of axle guard without clearances and with friction dampers with a special construction. Transverse suspension is partially achieved through flexi-coil spring effect (clearance $2 \times 10 \mathrm{~mm}$ ). The frame of the wagon is usually associated with a bogie through the centre pivot (radius $190 \mathrm{~mm}$ ) and its centre of $925 \mathrm{~mm}$ above the track at a weight of $20 \mathrm{t}$.

The bogie was originally designed for the load of $20 \mathrm{t} / \mathrm{axle}$ and maximum speed of $100 \mathrm{~km} / \mathrm{h}$ with base of $1800 \mathrm{~mm}$. During the development these parameters were upgraded. At present most bogies are designed for $22.5 \mathrm{t}$ axle load and the maximum speed increased up to $120 \mathrm{~km} / \mathrm{h}$ (depending on design arrangement). Wheel diameter is $920 \mathrm{~mm}$ and the wheelbase is $1800 \mathrm{~mm}$. The overall width of the bogie frame is $2440 \mathrm{~mm}$, width at the centre of the axle boxes is $2000 \mathrm{~mm}$ for $1435 \mathrm{~mm}$ track gauge [32, 33].

The Y25 bogie weight equipped with block brake is usually from 4.5 to $4.9 \mathrm{t}$. When we compare own weight of the original and modified bogie, we find that the new bogie (also equipped with block brake) weighs from $4.1 \mathrm{t}$ to $4.25 \mathrm{t}$.

\section{Computation of modal properties}

In case of modal analysis we solve characteristic oscillation of a frame structure without damping. Then, the equation of motion describing this system is:

$$
\boldsymbol{M} \cdot \ddot{\boldsymbol{q}}+\boldsymbol{K} \cdot \boldsymbol{q}=0,
$$

where $\boldsymbol{M}$ is the mass matrix,

$\boldsymbol{K}$ is the stiffness matrix and

$\ddot{\boldsymbol{q}}, \boldsymbol{q}$ represent vectors of node accelerations and displacement.

If we assume the dynamical system is moving harmonic and all degrees of freedom have the same phase angle the solution of equation (1) is following:

$$
\boldsymbol{q}=\boldsymbol{v} \cdot e^{i \cdot \Omega \cdot t}
$$

where $\boldsymbol{v}$ is the vector of oscillation amplitudes and

$\Omega$ is own angular frequency $[\mathrm{rad} / \mathrm{s}]$.

From equations (1) and (2) we get equation for eigenmodes and eigenfrequency calculation:

$$
(\boldsymbol{K}-\lambda \cdot \boldsymbol{M}) \cdot \boldsymbol{v}=0
$$

where $\lambda$ represents squares of wanted own frequencies 
$\left(\lambda=\Omega^{2}\right)[28,31]$.

For the modal analysis using the finite element method we have used Ansys software. It allows engineers to create computer models of structure, machine components or systems, apply operating loads and other design criteria and study physical responses, such as stress levels, pressure, etc.

Modal analysis process of bogie frame includes several steps, which are needed to perform for successful computation. We can describe it as follows [26]:

- CAD model - creation of the three-dimensional model of the bogie frame in Catia V5 software, generation of an appropriate model files;

- $\quad$ Setting up the FEM model in Ansys;

- Model automatic meshing by 8-nodes shell elements and 10-nodes quadratic tetrahedron elements (axle guides and centre pivot).

The frame is generally made of combination of $\mathrm{S} 235$ and S355 steels, which strength yields are $340-440 \mathrm{MPa}$ and $520-630 \mathrm{MPa}$, respectively. Therefore, we have defined these parameters of material model:

- Material - homogenous, isotropic, linear and elastic;

- Mechanical properties - Young's modulus of elasticity: $\quad E=2.1 \cdot 10^{11} \mathrm{~Pa}$, Poisson's ratio $\mu=0.3$.

Figure 3 shows FE mesh model of the bogie frame.

The boundary condition definition is the next necessary step before analysing. In our case, we have defined boundary conditions in the centre pivot, where all degrees of freedom (free displacement and three rotations) fixed. The fixed coupling of the frame in the centre pivot is shown in Fig 4.
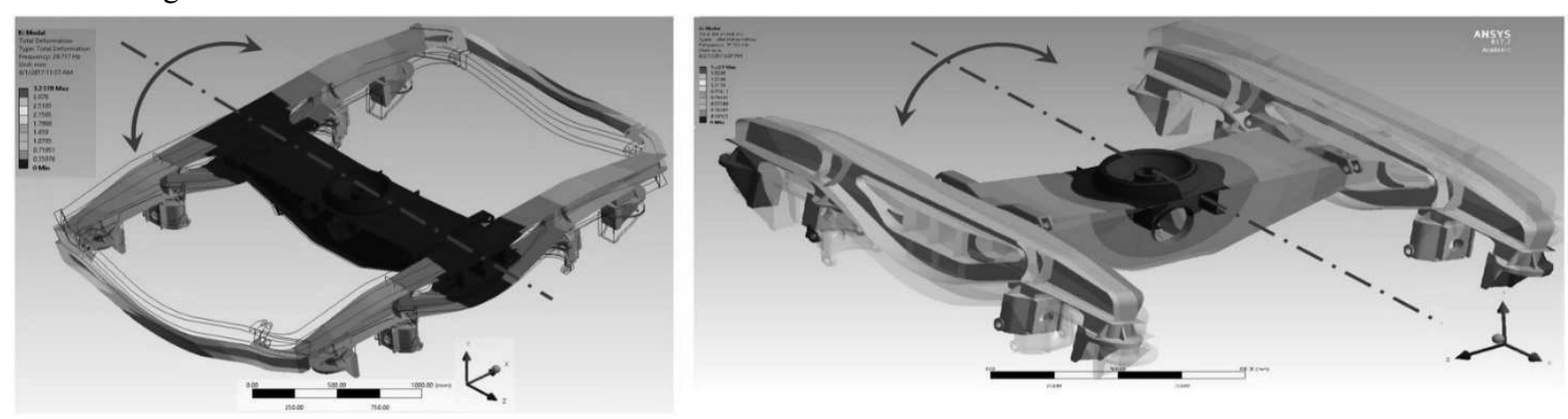

Fig. 4 Comparison of the $1^{\text {st }}$ eigenmodes
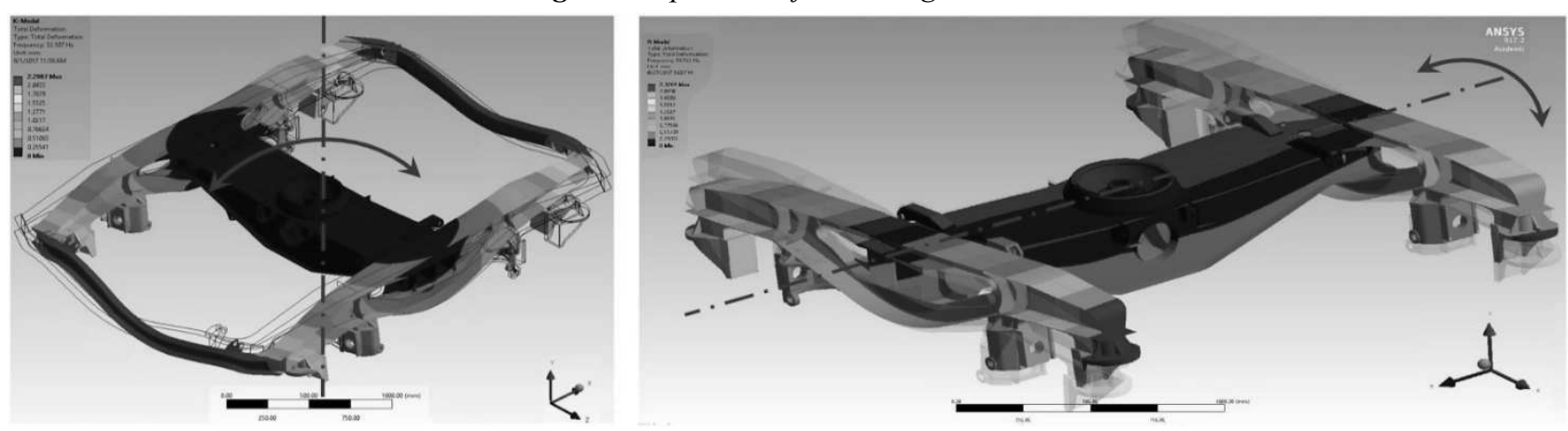

Fig. 5 Comparison of the $2^{\text {nd }}$ eigenmodes 

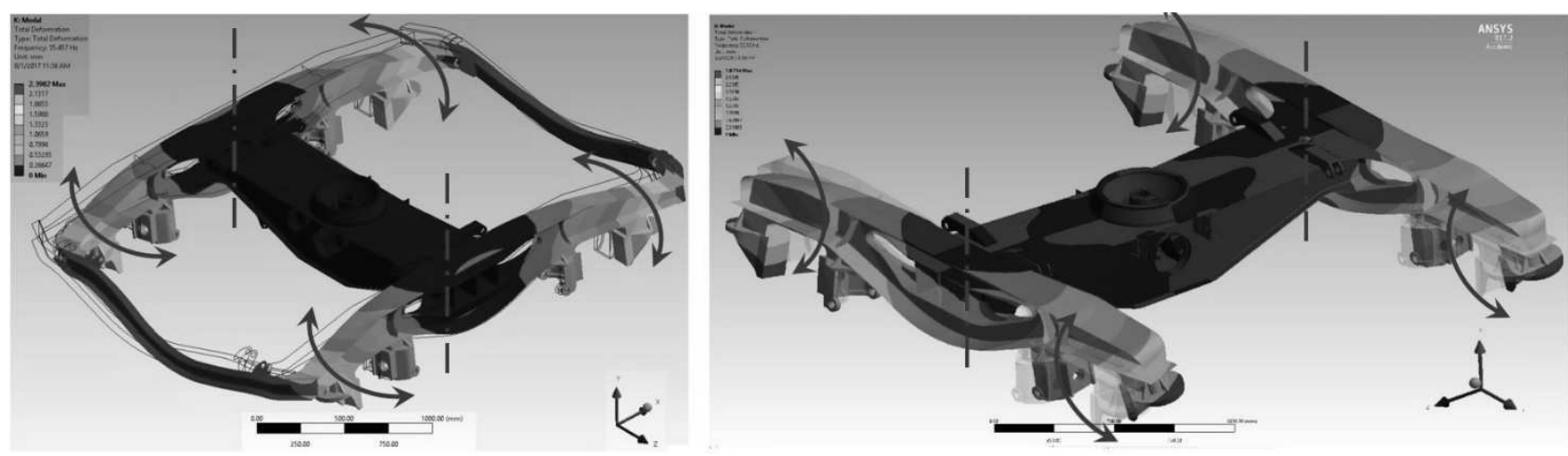

Fig. 6 Comparison of the $3^{\text {rd }}$ eigenmodes
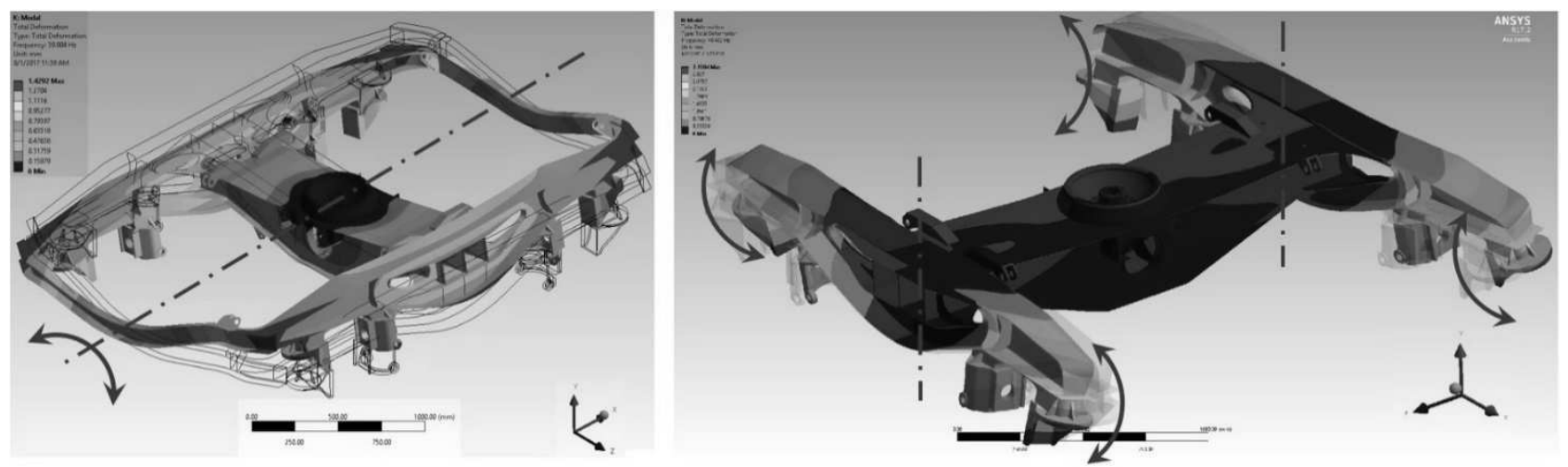

Fig. 7 Comparison of the $4^{\text {th }}$ eigenmodes
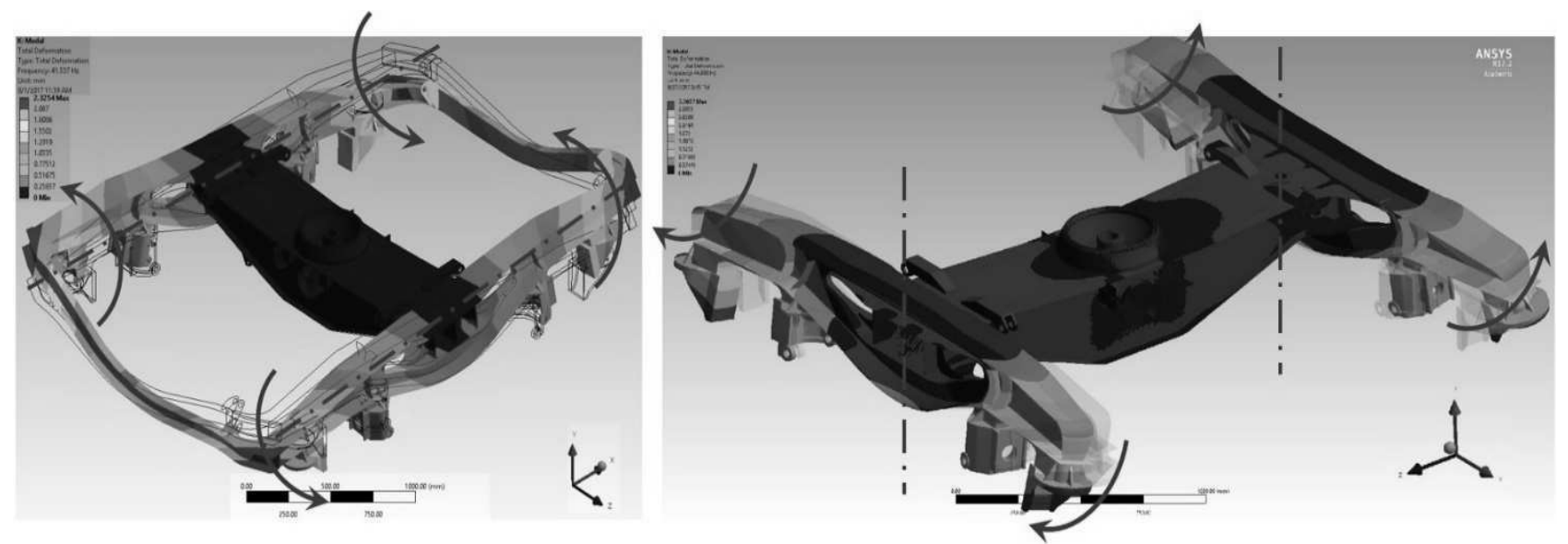

Fig. 8 Comparison of the $5^{\text {th }}$ eigenmodes
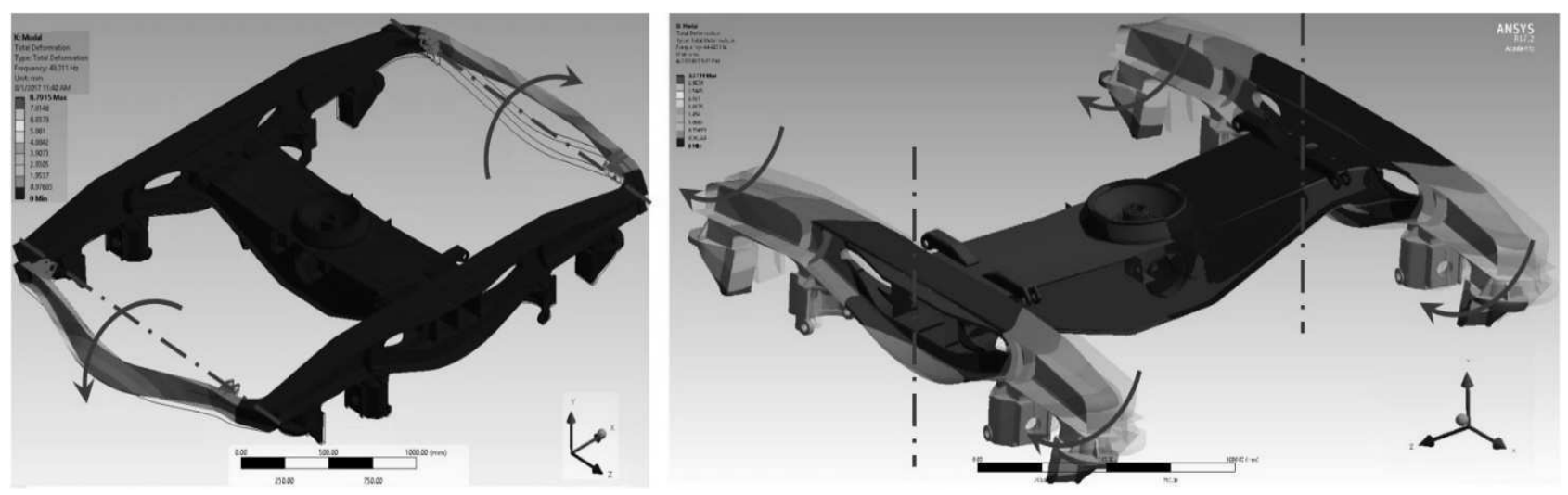

Fig. 9 Comparison of the $6^{\text {th }}$ eigenmodes

Calculated first six eigenfrequencies from the modal analysis attributable to first six eigenmodes are listed in 
Table 1. For comparison there are also listed eigenfreqencies (in the last column) of the original bogie frame (with buffer beams).

Tab. 1 Eigenfrequences of the original and modified freight wagon bogie frame

\begin{tabular}{|c|c|c|}
\hline & Original frame (with buffer beams) & Modified frame (without buffer beams) \\
\hline Eigenmode number & Eigenfrequency [Hz] & Eigenfrequency [Hz] \\
\hline $1^{\text {st }}$ mode & 29.717 & 35.372 \\
\hline $2^{\text {nd }}$ mode & 32.107 & 36.112 \\
\hline $3^{\text {rd }}$ mode & 35.457 & 38.180 \\
\hline $4^{\text {th }}$ mode & 39.904 & 40.422 \\
\hline $5^{\text {th }}$ mode & 41.537 & 44.088 \\
\hline $6^{\text {th }}$ mode & 48.311 & 44.427 \\
\hline
\end{tabular}

Let's have a look in Table 1. The value of the first eigenfrequency is $35.372 \mathrm{~Hz}$ and value of the sixth eigenfrequency is $44.427 \mathrm{~Hz}$. We can see, that this frequency range is relatively close. It means, that the frame will be excited in this frequency domain during the operation, the frame will be dynamically stressed what could has adverse effect on its structure.

When we compare results for the original and modified bogie frame, we find out, that the frequency difference is from $0.518 \mathrm{~Hz}$ ( $4^{\text {th }}$ mode) to $5.655 \mathrm{~Hz}$ ( $1^{\text {st }}$ mode). Hence, from our analyses and calculations we can assume, modal properties of the modified bogie frame are similar to the original bogie frame and dynamic properties would be also similar.

In the future we will research dynamic behaviour of the entire modified bogie. We will create mechanical system of the modified bogie in a multibody software and our just analysed FE model will serve as an important input for setting up a multibody system with a flexible body in order to study its dynamic properties and to compare with the original bogie for the detection of possible problems in terms of long-term operation.

Modal analysis is an important step for evaluation of dynamic properties whether it is a structure response, spectral analysis or the random vibration. Modal analysis allows better to understand a structure behaviour. Calculation of eigenmodes can help in modelling fails identification, e.g. incorrect boundary conditions, incorrect nodes connections etc.

Future research will be focused not only on the comparison of modal properties of the frame of the original and modified bogie, but also on the assessment of static and dynamic behaviour of entire bogies. Moreover, these FEM models of bogie frames will be used for importing into the MBS software $[2,3,8,9,26]$. After creation of a freight wagon multibody system with flexible bodies analyses will be performed and results from these computationsallow better assessemt of a rail vehicle ride properties.

\section{Conclusion}

Computational simulations are now an integral part of the development process of rolling stock. They allow a more detailed analysis of the behaviour of the vehicle as a whole or its individual parts. Therefore it is possible to better optimise the design of rail vehicles and prevent potential problems in the operation, which would require increased costs.

In modal analysis calculation of lowest eigenfrequences and eigenmodes is relevant, because on one hand they are most important from the structure dynamic properties point of view and on the other from the calculation point of view an accuracy of higher frequency finding is lower. Generally, number of required eignemodes in modal analysis depends on values of system eigenfrequencies and also on acting loads. Dynamic loads which frequencies are near to eigenfrequencies significant influence the response of a structure.

\section{Acknowledgement}

This article was supported by the project VEGA 1/0558/18: Research of the interaction of a braked railway wheelset and track in simulated operational conditions of a vehicle running in a track on the test stand.

The work was supported by the Cultural and Educational Grant Agency of the Ministry of Education of the Slovak Republic in project No. KEGA 077ŽU-4/2017: Modernization of the Vehicles and engines study program.

This work is the implementation result of the project: Modern methods of teaching control and diagnostics systems of engine vehicles ITMS 26110230107 supported by Operational Programme Education and funded European Social Fund.

\section{$\checkmark$ \VÝSKUMNÁ AGENTÚRA \\ Európska únia \\ Strukturàlne fondy}

\section{References}

[1] BITTNER, V., TUČEK, R., PANSKÁ, Š., SVOBODA, M., JELEN, K. (2017) Using the fourier transform in the analysis of vibration load tests of heterogenous mechanical systems. In: Manufacturing Technology, Vol. 17, No. 6, pp. 836-841, ISSN 1213-2489.

[2] BULÍN, R., HEJŽMAN, M., POLACH, P., ŠIKA, Z., ZAVŘEL, J. (2017) Dynamical analysis of a cable manipulator using multibody approaches. 
In: Manufacturing Technology, Vol. 17, No. 2, pp. 152-157, ISSN 1213-2489.

[3] BULÍN, R., HEJŽMAN, M., POLACH, P. (2018) Complex modelling and dynamical analysis of parallel cable mechanisms. In: Multibody Mechatronic Systems. MuSMe 2017. Mechanisms and Machine Science, (Carvalho J., Martins D., Simoni R., Simas H., (Ed.)), vol 54. Springer, Cham, Online ISBN 978-3-319-67567-1.

[4] GERLICI, J., GORBUNOV, M., KRAVCHENKO, K., DOMIN, R., KOVTANETS, M., LACK, T. (2017) Slipping and skidding occurrence probability decreasing by means of the friction controlling in the wheel-braking pad and wheel-rail contacts. In: Manufacturing Technology, Vol. 17, No. 2, pp. 179-186, ISSN 1213-2489.

[5] GERLICI, J., LACK, T. (2009) Iterative method for railway wheel profile design. In: Komunikacie, Vol. 11, No. 2, pp. 49-56, ISSN 1335-4205.

[6] GERLICI, J., LACK, T. (2014) Modified HHT method for vehicle vibration analysis in time domain utilisation. In: Applies Mechanics and Materials, Vol. 486, pp. 396-405, ISSN 1660-9336.

[7] GERLICI, J., LACK, T. (2014) Rail vehicles brake components test bench utilisation. In: $A p$ plies Mechanics and Materials, Vol. 486, pp. 379386, ISSN 1660-9336.

[8] HAUSER, V., NOZHENKO, O. S., KRAVCHENKO, K. O., LOULOVÁ, M., GERLICI, J., LACK, T. (2017) Impact of wheelset steering and wheel profile geometry to the vehicle behaviour when passing curved track. In: Manufacturing Technology, Vol. 17, No. 3, pp. 306-312, ISSN 1213-2489.

[9] HAUSER, V., NOZHENKO, O., KRAVCHENKO, K., LOULOVÁ, M., GERLICI, J., LACK, T. (2017) Proposal of a steering mechanism for tram bogie with three axle boxes. In: Procedia Engineering, Vol. 192, pp. 189-294, ISSN 1877-7058.

[10] HAUSER, V., NOZHENKO, O. S., KRAVCHENKO, K. O., LOULOVÁ, M., GERLICI, J., LACK, T. (2017) Proposal of a mechanism for setting bogie wheelsets to radial position while riding along track curve. In: Manufacturing Technology, Vol. 17, No. 2, pp. 186-192, ISSN 1213-2489.

[11] KAŠIAR, L', ZVOLENSKÝ, P., BARTA, D., BAVLNA, L., MIKOLAJČÍK, M., DROZDZIEL, P. (2016) Diagnostics of electric motor of locomotive series 757. In: Diagnostyka, Vol. 17, No. 3, pp. 95-101, ISSN 1641-6414.
[12] KLIMENDA, F., RYCHLÍKOVÁ, L., HUSÁR, S., SOUKUP, J. (2017) Dissemination of waves in thin plates. In: Manufacturing Technology, Vol. 17, No. 6, pp. 863-869, ISSN 1213-2489.

[13] KLIMENDA, F., SKOČILASOVÁ, B. (2015) Rollers vibration of pipe conveyor. In: Manufacturing Technology, Vol. 15, No. 6, pp. 991-995, ISSN 1213-2489.

[14] KLIMENDA, F., SOUKUP, J. (2017) Modal analysis of thin aluminium plate. In: Procedia Engineering, Vol. 177, pp. 11-16, ISSN 1877-7058.

[15] KOSTRZEWSKI, M., CHUDZIKIEWICZ, A. (2014) Rail-track quality indicator towards rail vehicle driving dynamics. In: Proceedings of the Mini Conference on Vehicle System Dynamics, Identification and Anomalies, VSDIA 2014, (I. Zobory, (Ed.)), pp. 211-218. Budapest: Budapest University of Technology and Economisc.

[16] KOSTRZEWSKI, M., MELNIK, R. (2017) Numerical dynamic study of a rail vehicle with differential gears. In: Proceedia Engineering, Vol. 192, pp. 439-444, ISSN 1877-7058.

[17] KULHAVÝ, P., LEPSIK, P. (2017) Comparison of modal characteristic of wrapped and winded composite tubes from carbon prepreg. In: Vibroengineering Proceedia, Vol. 11, May 2017, pp. 91-96, ISSN 2345-0533.

[18] LACK, T., GERLICI, J. (2014) A modified strip method to speed up the calculation of normal stress between wheel and rail. In: Applied Mechanics and Materials, Vol. 486, pp. 359-370, ISSN 1660-9336.

[19] LACK, T., GERLICI, J. (2009) Railway wheel and rail roughness analysis. In: Communications Scientific Letters of the University of Žilina, Vol. 11, No. 2, pp. 41-48, ISSN 1335-4205.

[20] LACK, T., GERLICI, J. (2013) The FASTSIM method modification to speed up the calculation of tangential contact stresses between wheel and rail. In: Manufacturing Technology, Vol. 13, No. 4, pp. 486-492, ISSN 1213-2489.

[21] LACK, T., GERLICI, J. (2014) Wheel/rail tangential contact stress evaluation by means of the modified strip method. In: Communications - Scientific Letters of the University of Žilina, Vol. 16, No. 3, pp. 33-39, ISSN 1335-4205.

[22] LACK, T., GERLICI, J., MAŇUROVÁ, M. (2016) Freight car bogie properties analysis by means of simulation computations. In: Manufacturing Technology, Vol. 16, No. 4, pp. 733-739, ISSN 1213-2489. 
[23] LENDEL, V., PANCIKOVA, L., FALAT, L., MARCEK, D. (2017) Intelligent modelling with alternative approach: Application of advanced artificial intelligence into traffinc management. In: Communications - Scientific Letters of the University of Žilina, Vol. 19, No. 4, pp. 36-42, ISSN 1335-4205.

[24] LUNYS, O., DAILYDKA, S., STEIŠŪNAS, S., BUREIKA, G. (2016) Analysis of freight wagon wheel failure detection in Lithuanian Ralways. In: Procedia Engineering, Vol. 134, pp. 64-71, ISSN 1877-7058.

[25] MAŇUROVÁ, M., SUCHÁNEK, A. (2016) Determination of stiffness of triple spring built in a bogie of a rail vehicle. In: Manufacturing Technology, Vol. 16, No. 2, pp. 390-396, ISSN 12132489.

[26] MAŇUROVÁ, M., SUCHÁNEK, A. (2016) The analysis of a rail vehicle with a tilting bogie. In: Manufacturing Technology, Vol. 16, No. 5, pp. 1020-1027, ISSN 1213-2489.

[27] MELNIK, R., SOWINSKI, B. (2013) Application of the rail vehilce's monitoring system in the process of suspension condition assessment. In: Komunikacie, Vol. 15, No. 4, pp. 3-8, ISSN 13354205.

[28] SKOČILASOVÁ, B., SKOČILAS, J. (2015) Nusselt number criteria equations in the cross flow over single tube. In: Manufacturing Technology, Vol. 15, No. 6, pp. 1043-4048, ISSN 1213-2489.

[29] SMETANKA, L., ŠŤASTNIAK, P. (2017) Analysis of contact stresses of theoretical and worn pro- file by using computer simulation. In: Manufacturing Technology, Vol. 17, No. 4, pp. 580-585, ISSN 1213-2489.

[30] SOUKUP, J., SKOČILASOVÁ, B., SKOČILAS, J. (2017) Vibration of mechanical system with higher degrees of freedom: Solution of the frequency equations. In: Proceedia Engineering, Vol. 177 , pp. 17-24, ISSN 1877-7058.

[31] SVOBODA, M., SOUKUP, J., PETRENKO, A. (2014) Use of FEM programs in solving general unbalance simple mechanical system of rigid, flexible stored bodie. In: Proceedings of EAN 2014 $-52^{\text {nd }}$ International Conference on Experimental Stress Analysis, ISBN 978-8-023-10377-6.

[32] ŠŤASTNIAK, P., SMETANKA, L., MORAVČÍK, M. (2017) Development of modern railway bogie for broad track gauge - Bogie frame assessment. In: Manufacturing Technology, Vol. 17, No. 2, pp. 250-256, ISSN 1213-2489.

[33] SUCHÁNEK, A., LACK, T., KALINČÁK, D. (2015) Structural design of opening-roof in freight wagon (In Slovak). In: Technológ, Vol. 7, No. 2, pp. 206-210.

[34] VAIČŪNAS, G., BUREIKA, G., STEIŠŪNAS, S. (2018) Research on metal fatique of rail vehicle wheel considering the wear intensity of rolling surface. In: Eksploatacja i Niezawodnosc, Vol. 20, No. 1, pp. 24-29, ISSN 1507-2711.

[35] ZVOLENSKÝ, P., KAŠIAR, L., VOLNA, P., BARTA, D. (2017) Simulated computation oft he acoustic energy transfer through the structure of porous media in application of passenger carriage. In: Proceedia Engineering, Vol. 187, pp. 100-109, ISSN 1877-7058. 